Pitak I., Shaporev V., Briankin 5., Pitak 0.

\title{
JUSTIFICATION OF THE CALCULATION METHODS OF THE MAIN PARAMETERS OF VORTEX CHAMBERS
}

На основі побудови наближеної моделі руху дисперсного потоку у вихровому апараті здобуті аналітичні вирази для визначення швидкості дрейфу часток пилу за напрямком до стінки апарату. Проведені розрахунки щодо усереднення тангенційної і вісьової складової швидкості газового потоку. 3 використанням вказаних аеродинамічних параметрів газового потоку визначена ефективність пиловловлення у вихрових апаратах.

Ключові слова: вихровий апарат, навколишнє середовище, дисперсний потік, газовий потік, швидкість газу.

\section{Introduction}

One of the most urgent problems facing industry today is the improvement of equipment and technology for protecting the environment as a whole and, in particular, reducing the dustiness of atmospheric air and bringing the concentration of aerosols in admissible norms in exhaust gases. As a rule, when dusty products are caught one of the main technological stages is the «dry» dust collection stage, which is realized in various apparatus. Modern methods of air cleaning from dust based on the use of apparatus in which hydrodynamic conditions are associated with the use of swirling vortex flows [1, 2]. This direction of calculation and justification of the design and operating parameters of dust collectors, with the aim of increasing the efficiency of dust removal of gases, is considered the most modern and promising [1,2] and is inherent in almost all industries: chemical, metallurgical, construction, food and others.

\section{The object of research and its technological audit}

The object of research is dust collectors. These apparatus, in which the above-mentioned hydrodynamic regimes are realized, are usually referred to vortex apparatus.

The general view of a vortex dust collector in the form of a vortex chamber is shown in Fig. 1.

Dust-free exhaust gas is fed into the inlet nozzle (1), passes through the vane-shaped swirler (2), then enters the cavity of the apparatus (3). The secondary gas flow through the distribution box (5) and the nozzles (4) is fed toward the swirling flow moving in the cavity 3 . With these nozzles, it twists in the opposite direction from the twist of the main flow, which leaves through the swirler (2). As a result of the movement and rotation of the flows, the dust is concentrated in the form of a layer near the outer walls of the cylindrical apparatus (3) and flows into the bunker (6) in a dense layer, and then is discharged from the apparatus through the dust seal (8). Dust-free gas moves in the central part in the zone of the axis and is discharged from the apparatus through the washer.

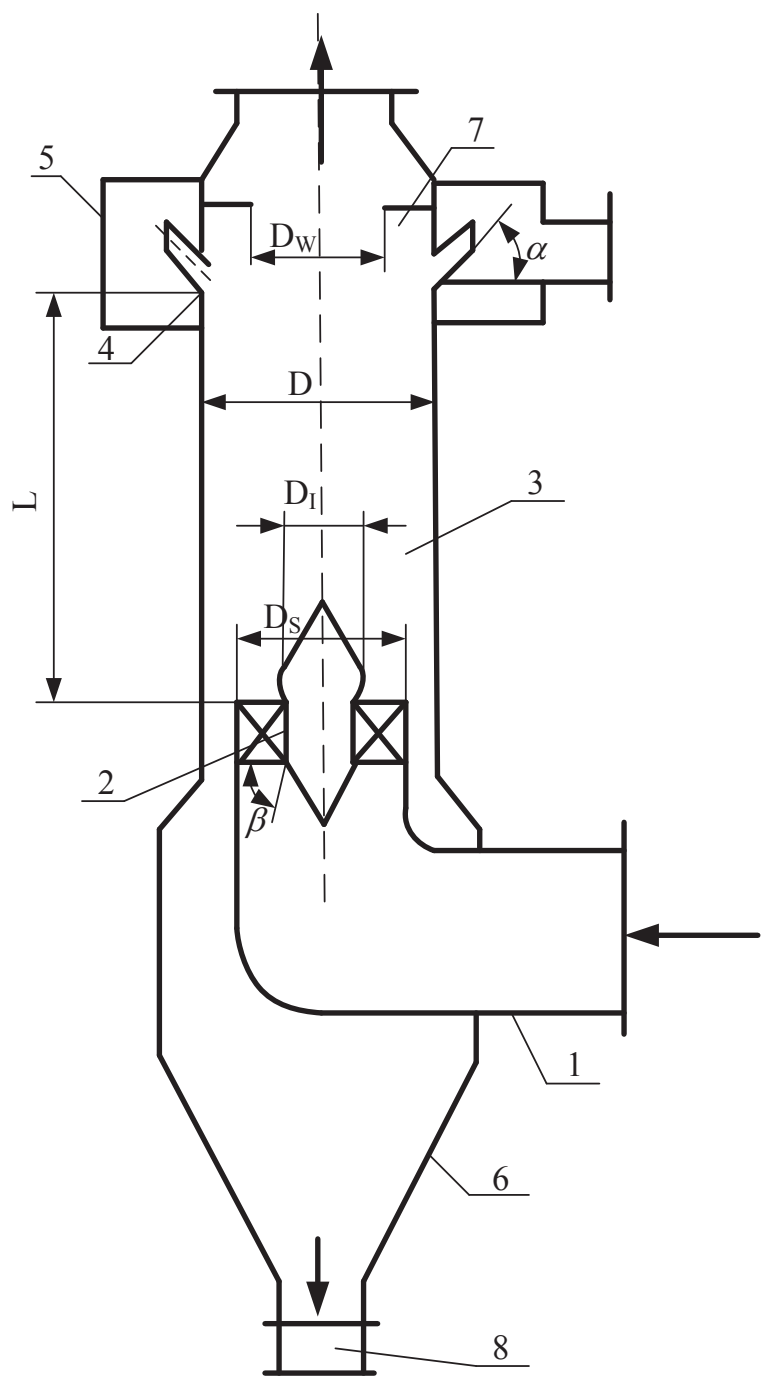

Fig. 1. General view of the vortex chamber for dust collection: 1 - inlet nozzle; 2 - vane-shaped swirler; 3 - body of the apparatus; 4 - secondary flow nozzles; 5 - secondary flow distribution box; 6 - bunker; 7 - washer; 8 - dust seal

Advantages of using vortex apparatus: work with gases of high temperature, high degree of purification; regulation 
of the process of gas cleaning from dust due to regulating the secondary air flow. Among the disadvantages of vortex dust collectors are: high hydraulic resistance, the need for powerful blowing apparatus, as well as difficult operation and installation.

\section{The aim and objectives of research}

The aim of research is substantiation of the methods for calculating the basic parameters of the vortex chambers.

To achieve this aim, it is necessary:

1. To consider mathematical dependencies on the conditions of the process of dry gas flow cleaning from dust.

2. To carry out predictive evaluations to select the conditions for the dry gas cleaning process from dust.

3. To select the design parameters of the vortex chamber.

4. To determine the velocity of dust particles in the vortex flow, as well as the basic relationships of structural dimensions in the vortex chamber.

\section{Research of existing solutions of the problem}

The theoretical foundations of the motion of swirled viscous gas flows in pipes and curvilinear channels, energy transfer in adiabatic gas flows, for homogeneous and for dispersion gas flows, is fundamentally justified in [3-5]. According to these works, the rational organization of one or another swirling flow depends on the function $\alpha$, which is defined by the relation:

$$
\alpha=\frac{C_{\theta} r}{C_{M} R}
$$

where $C_{\theta}$ - circumferential velocity; $r$ - current radius value; $C_{M}$ - maximum rate of flow into the void; $R$ - the outer radius of the channel.

This is the so-called «law of swirl» of nozzle or directing apparatus when entering the gas flow into the vortex apparatus

These apparatus for swirling the flow have a different design and, depending on the gas flow rate, pressure and physicochemical properties of the gas flow at the inlet to the purification apparatus, this or that hydrodynamic regime is created therein. So known methods of flow swirling are related:

- with tangential flow input (tangential nozzles, cochlear snail);

- with the installation of rings, twist (with tangential slots, round tangential holes and tangential nozzles);

- vane-shaped vortex (different angles of vane direction);

- twist of the flow due to the intersection of electric and magnetic fields.

According to these methods of flow swirling at the entrance to the dust collecting vortex apparatus can be classified as cyclones, vortex tubes, vortex chambers, gas centrifuges and others. If gas flow enters the swirler (directing apparatus) and in the apparatus itself, the flow proceeds at Re numbers greater than $10^{6}$ (the incoming flow velocity is more than $50 \mathrm{~m} / \mathrm{s}$ ). After that, immediately behind the end of the apparatus and around several calibers behind it arise similar torus-shaped and other vortex structures (for example, the Gertler vortices) [6, 7].
This hydrodynamic regime provides intensive dissipation of the mechanical energy of the flow, internal heat release and an uneven distribution of the inhibition temperature, and as a result, the Rank effect appears. Typically, the described mode occurs in such apparatus as a vortex tube and a gas centrifuge. In other apparatus such as cyclones and vortex chambers, the conditional velocity of the main gas flow in the working cavity of the dust collector is less than $10-20 \mathrm{~m} / \mathrm{s}$. The latest apparatus are widely used to trap dust products in the industry, taken out of furnaces, dryers, products that are transported by pneumatic transport, ash and dust from the smoke gases of boiler plants, etc. [8]. Calculation and choice of the design of such apparatus is associated with the need to preliminarily determine the radial velocity of dust particles of a given disperse composition, the flow rates of the flow from the channels of the blade-shaped swirlers, the velocity of the secondary flow out of the nozzles, and the like. As noted in [9-11], the theory of operation of these apparatus has not yet been improved and does not make it possible to calculate apparatuses of various designs. By this time only the empirical method is possible to solve the issue of beneficial design forms of dust collecting apparatus.

\section{Methods of research}

When designing vortex chambers, the following design parameters must be followed (Fig. 1): $L / D \approx 2.5 \div 3.5$; $D_{s} / D \approx 0.8 ; D_{i} / D_{s} \approx 0.5 ; D_{w} / D \approx 0.5 \div 0.8$; the inclination angle of the vortex blades at the inlet of the main flow is $\beta \approx 30 \div 60^{\circ}$; the inclination angle of the secondary flow nozzles is $\alpha \approx 30 \div 45^{\circ}$. The above relations are based on an analysis of the results of the studies [10-12], in which the models of swirling dispersed circular flows in a smooth cylindrical tube with a swirler are considered, numerical study of models, experiments of mixing oppositely swirled flows and others are experimentally investigated.

The efficiency of the vortex chamber is determined from the conditions for the equality of the drift time of the aerosol from the chamber axis to its walls and the residence time of the gas in the apparatus, that is:

$$
\frac{D-l}{2 \overline{V_{r}}}=\frac{L}{\overline{W_{0}}}
$$

where $L$ - diameter of the conventional gas cylinder (m), in which all the uncollected dust in the apparatus is concentrated, the physical-chemical parameters of the gas and the dust concentration correspond to the initial ones.

For calculations it is possible to take both the conditional velocity of the main gas flow in the working part of the chamber, while, as shown by practical studies $[8,12]$ $7 \leq \overline{W_{0}}<15 \mathrm{~m} / \mathrm{s}$, and $\overline{W_{0}}$ is determined by the relation:

$$
\overline{W_{0}} \approx \frac{4 Q_{1}}{\pi D^{2}},
$$

where $Q_{1}$ - volume of purified gas, $\mathrm{m}^{3}$ /hour.

Then the efficiency equal to the ratio of the collected dust to all dust entering the apparatus will be:

$$
\eta=1-\left(\frac{l}{D}\right)^{2} \text { or } \eta=\frac{2 L \overline{W_{0}}}{D \overline{W_{0}}}\left(2-\frac{2 L \overline{V_{r}}}{D \overline{W_{0}}}\right) \text {. }
$$


This proves that this function has an extremum (the maximum efficiency value equal to one) for $\frac{2 L \overline{V_{r}}}{D \overline{W_{0}}}=1$.

\section{Research results}

In the theoretical analysis of the motion of aerosol particles in the working cavity of the apparatus, it is necessary to determine the real velocity of dust particles of a given disperse composition $\bar{V}_{r}$. To this end, let's consider the motion equation of dust particles with a constant reduced diameter $\mathrm{d}$ and mass $\mathrm{m}$ in the radial direction. In this direction, a particle of dust is acted upon: the force, pressure and aerodynamic drag along the center (in the case of using an electric-vortex apparatus, an additional electric force arises, increases the radial velocity of the particles). In accordance with Newton's second law of the equation of motion takes the form:

$$
\begin{aligned}
& m_{D} \cdot \frac{d V_{r}}{d \tau}=m_{D} \cdot \frac{\theta^{2} V_{r}^{2}}{r}-\frac{\pi d^{2}}{4} \cdot \frac{\partial P}{\partial r} d r- \\
& -C_{X} \cdot \frac{\pi d^{2}}{4} \rho \cdot \frac{\left(V_{r}-V_{R}\right)^{2}}{2}+A_{E} d^{2},
\end{aligned}
$$

where $A_{E}=\varepsilon_{o} \cdot \delta \cdot E_{c} \cdot E_{d} ; E_{c}, E_{d}$ - voltage of the electric field strength of the charging and deposition zones, respectively, $\mathrm{V} / \mathrm{m} ; \varepsilon_{0}-$ electrical permittivity of vacuum, $\mathrm{F} / \mathrm{m}$; $\delta$ - dielectric constant of dust; $\rho$ - gas density, $\mathrm{kg} / \mathrm{m}^{3}$; $P$ - gas flow pressure, Pa; $C_{x}$-aerodynamic drag coefficient; $\theta-$ slip coefficient of the aerosol relative to the gas flow in the radial direction; $V_{r}$ and $V_{R}$-respectively radial velocity of aerosol and gas flow, $\mathrm{m} / \mathrm{s}$.

After dividing all the terms of equation (4) by the value $m_{D}=\rho_{D} \frac{\pi d^{2}}{6}$ and performing the transformations, obtain:

$$
\begin{aligned}
& \frac{d V_{r}}{d \tau}=f V_{r}^{2}+g V_{r}+h ; \\
& f=-3 / 4 \cdot C_{X} \frac{\rho}{\rho_{D}} \cdot \frac{1}{d} ; \\
& g=3 / 2 \cdot C_{X} \frac{\rho}{\rho_{D}} \cdot \frac{V_{R}}{d} ; \\
& h=\frac{\theta^{2} \cdot V_{\tau}^{2}}{r}-\left(\frac{3}{4} \cdot C_{X} \frac{\rho}{\rho_{D}} \cdot \frac{V^{2}}{d}-\frac{3}{2} \cdot \frac{\partial P}{\partial r} d r \frac{1}{\rho_{D} d}\right),
\end{aligned}
$$

where $V \tau$ - tangential velocity of the gas flow, $\mathrm{m} / \mathrm{s} ; d-$ particle diameter, $\mathrm{m}$.

According to [13], in equation (6):

$$
U=\exp \int-V_{r}(\tau) f(\tau) d \tau,
$$

where $U-$ the solution of the linear differential equation:

$$
U^{\prime \prime}+a u^{\prime}+b u=0 ; \quad(a=-g ; b=f h),
$$

as for $D=a^{2}-4 b>0$ has the form:

$$
U=C_{1} \exp \frac{-a+\sqrt{D}}{2} \tau+C_{2} \exp \frac{-a-\sqrt{D}}{2} \tau .
$$

In equation (8), the values of the integration constants:

$$
C_{1}=\frac{\lambda+a}{2 \lambda} ; C_{2}=\frac{\lambda-a}{2 \lambda} \text {. }
$$

Found under the initial conditions:

$$
\tau=0 ; V_{r}(\tau)=0 ; u=1 \text { and } \tau=0 ; \frac{d V_{r}}{d \tau}=0 ; u^{\prime \prime}=0,
$$

from equation (7) it follows that:

$$
V_{r}(\tau)=\frac{1}{f u} \cdot \frac{d u}{d \tau}
$$

Having determined $\frac{d u}{d \tau}$ from equation (8) with allowance for (9) and substituting it in (10), let's obtain an analytical expression for the radial velocity of a dust particle in a vortex flow:

$$
V_{r}(\tau)=\frac{b}{\lambda \tau u} \cdot\left[\exp \left(\frac{\lambda-a}{2} \tau\right)-\exp \left(\frac{-\lambda+a}{2} \tau\right)\right]
$$

If ignore the electric forces and take into account the effect of only the centrifugal forces and the viscous resistance on the particles, then the velocity of the particles to the wall of the apparatus can be approximated by the equation:

$$
\overline{V_{r}}(\tau)=\frac{d^{2} \bar{V}_{\tau}^{2} \rho_{D}}{18 R \eta},
$$

where $\bar{V}_{\tau}$ - the averaged tangential component of the gas flow velocity in the working cavity of the apparatus, $\mathrm{m} / \mathrm{s}$; $\eta$ - dynamic density of the gas source, $\mathrm{kgf} / \mathrm{m}^{2} ; R$ - radius of the apparatus, $\mathrm{m}$.

Fig. 2 shows the graphical dependencies $\overline{V_{r}}(\tau)=f\left(\overline{V_{\tau}}\right)$ for different values of the complex $\frac{d^{2} \rho_{D}}{18 R \eta}$ calculated using a computer.

When calculating and designing a vortex chamber, it is necessary to fulfill the conditions for the constancy of the tangential velocity of the total flow along the entire length of the working cavity of the apparatus, ensuring the maximum possible efficiency of its functioning. To fulfill these conditions, the velocity of the gas flow out of the nozzles (Fig. 1, pos. 4) should be 1.5-3 times more tangential flow velocity at the exit from the vane-shaped swirler:

$$
Q_{2}=(0.25 \div 0.65) \cdot Q_{1},
$$

where $Q_{1}$ - volume of secondary flow, $\mathrm{m}^{3} /$ hour.

The velocity of flow out of the channels of the vaneshaped swirler is determined from the Bernoulli equation written for the real flow [1]:

$$
W=0,91 \sqrt{\frac{2 \Delta \mathrm{H}}{\rho_{1}}},
$$

where $\Delta \mathrm{H}-$ head loss in the swirler, mm Hg.; $\rho_{1}-$ main flow density, $\mathrm{kg} / \mathrm{m}^{3}$. 


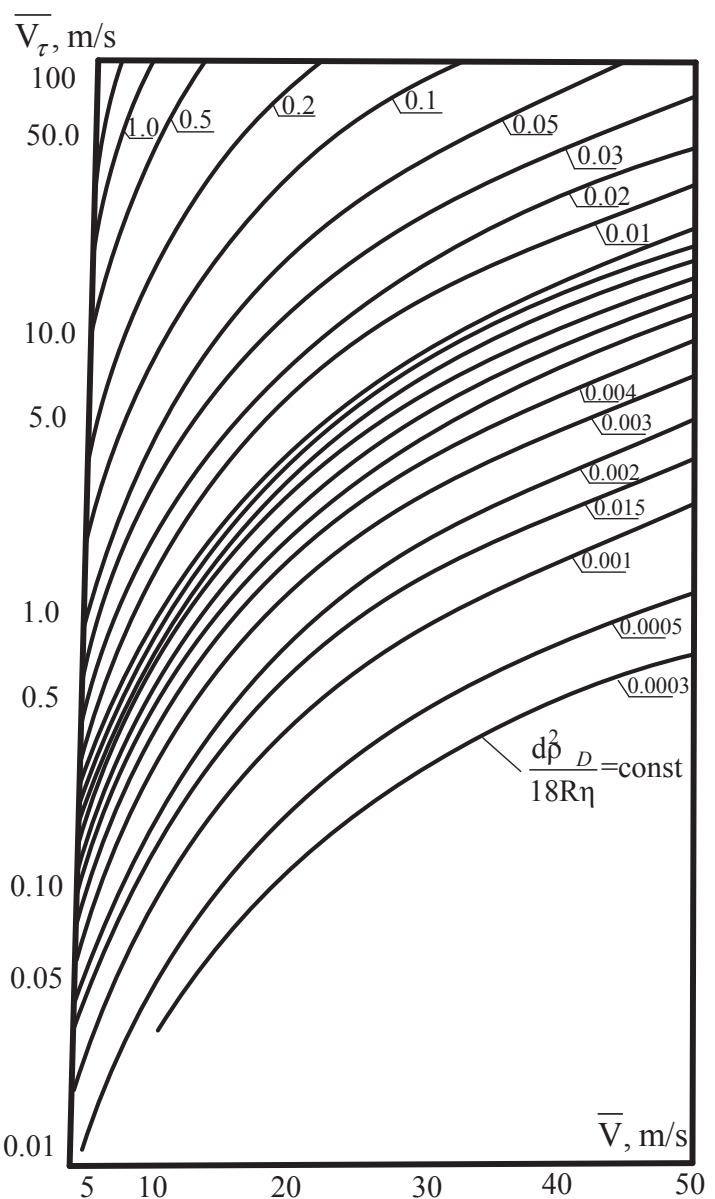

Fig. 2. Dependence of the velocity of particles to the walls of the apparatus on the average tangential velocity of the gas flow for various complexes $\frac{d^{2} \rho_{D}}{18 R \eta}$

In fact, it is impossible to provide an ideal unstressed flow inlet in the dust collecting apparatus, therefore, the empirical coefficient $k=0.5 \div 0.7$ is introduced into the calculation formula (13) for determining the flow outflow rate.

The axial component of the gas flow velocity at the outlet from the vortex is:

$$
W_{\text {a.s. }}=k \cdot 0,91 \sin \beta \sqrt{\frac{2 \Delta \mathrm{H}}{\rho_{1}}} .
$$

The conditional axial velocity in the apparatus $W_{a}$ is related to the axial velocity in the swirler $W_{a . s .}$ conditions of continuous flow:

$$
W_{\text {a.s. }}=\overline{W_{a}} \frac{1}{\left(\frac{D_{s}}{D}\right)^{2}\left[1-\left(\frac{D_{i}}{D_{s}}\right)^{2}\right]} .
$$

The flow velocity at the wall in the swirling region $V_{L}$, which depends on the requirements imposed on the flow that is downward should not be less than $1 \mathrm{~m} / \mathrm{s}$. In this case, the nozzle diameter $d_{n}$ and the initial flow velocity $V_{n}$ associated with the length of the working chamber and the inclination angle of the nozzles by the relation [14]:
$\frac{V_{k}}{V_{n}}=\frac{0,48 d_{n} \sin \alpha}{a L}$.

The value $\alpha$ is taken in the interval $0.085 \div 0.11$.

The rate of flow of the secondary flow from the nozzles in accordance with [14] is determined by the dependence:

$$
V_{n}=0,78 \sqrt{\frac{2 \Delta P}{\rho_{2}}},
$$

where $\Delta P$ - head loss in nozzles, mm. Hg.; $\rho_{2}-$ density of secondary flow, $\mathrm{kg} / \mathrm{m}^{3}$.

The number of nozzles for secondary flow is:

$$
n=\frac{4 k_{1} Q_{1}}{\pi d_{n}^{2} V_{n}}
$$

where $k_{1}$ - the coefficient that depends on the particle size of the dust (0.25-0.65), the large values of this coefficient correspond to finely dispersed fractions.

It is determined in [15] that for a dust with a fractional composition of $<10 \mu \mathrm{m}$, this coefficient, which depends on the particle size, is $k_{1} \approx 0.4 \div 0.5$; with a fractional composition of $10 \div 20 \mu \mathrm{m} k_{1} \approx 0.4 \div 0.5$; with a fractional composition of $>50 \mu \mathrm{m} k_{1} \approx 0.25 \div 0.3$.

The obtained mathematical dependences do not contradict the known approaches to the selection and calculation of dust collectors.

\section{SWOT analysis of research results}

Strengths. The strength of the approach presented in the work is that the obtained mathematical dependencies for a known distribution of dust particles in size allow to preliminarily determine the main design ratios of the dust collector at the given costs of the gas supplied for cleaning and the given efficiency of the dust collector.

Analysis of the obtained results for justification of the methods for calculating the basic parameters of the vortex chambers indicates the expediency of using such methods for calculating gas cleaning equipment.

When implementing the process of cleaning dust-gas flows in vortex apparatus, not only the processes of agglomeration of dust are observed, but also the destruction of gas toxicants.

Weaknesses. The main weaknesses of vortex dust collectors are the need for an additional blower apparatus for secondary gas supply, the complexity of manufacturing and operation, the lack of engineering calculation methods because of the complexity of the processes taking place in them.

Opportunities. Mathematical dependencies are considered to allow predictive estimations to be made to select the conditions of the dry dust removal process and to select the design parameters of the vortex chamber. This opens prospects for the introduction of vortex apparatus in order to reduce the industrial negative impact on the environment, namely the atmosphere.

Threats. Enterprises will need to increase the capital costs of installing new or improved gas cleaning equipment. Capital costs for the introduction of gas cleaning equipment are one-time. 


\section{Conclusions}

1. The mathematical dependences on the choice of conditions for the process of dry cleaning of the gas flow from dust and calculation of dust collection apparatus are obtained. The rational organization of one or another swirling flow depends on the function $\alpha$, which is determined by the «law of twist» of the nozzle or guide apparatus when the gas flow enters the vortex apparatus.

2. It is determined that the coefficient that depends on the particle size varies depending on the change in the fractional composition of the dust. For dust with a fractional composition of $<10 \alpha \mu \mathrm{m}$, the coefficient depends on the particle size and is $k_{1} \approx 0.6 \div 0.65$; with a fractional composition of $10 \div 20 \mu \mathrm{m} \quad k_{1} \approx 0.4 \div 0.5$; with a fractional composition of $>50 \mu \mathrm{m} \quad k_{1} \approx 0.25 \div 0.3$. The obtained mathematical dependences do not contradict the known approaches to the selection and calculation of dust collectors.

3. The mathematical dependencies, which allow to determine preliminary the basic design relationships of the dust collector at the given gas flow rates and the specified efficiency of the dust collector. In particular, when constructing vortex chambers, the following design parameters must be followed: $L / D \approx 2.5 \div 3.5 ; D_{s} / D \approx 0.8$; $D_{i} / D_{s} \approx 0.5 ; D_{w} / D \approx 0.5 \div 0.8$; the inclination angle of the vortex blades at the inlet of the main flow is $\beta \approx 30 \div 60^{\circ}$; the inclination angle of the secondary flow nozzles is $\alpha \approx 30 \div 45^{\circ}$.

4. The velocity of dust particles in a vortex flow is determined, as well as the basic ratios of the structural dimensions of the vortex chamber. When calculating and designing a vortex chamber, it is necessary to fulfill the conditions for the constancy of the tangential velocity of the total flow along the entire length of the working cavity of the apparatus, ensuring the maximum possible efficiency of its functioning. To fulfill these conditions, the rate of flow of the gas flow from the nozzles should be 1.5 to 3 times greater than the tangential flow velocity at the exit from the vane-shaped swirler.

\section{References}

1. Konovalov, V. I. Design Calculation of Ranque-Hilsch Vortex Tubes [Text] / V. I. Konovalov, A. Yu. Orlov, T. Kudra // Vestnik Tambovskogo gosudarstvennogo tehnicheskogo universiteta. - 2012. - Vol. 18, No. 1. - P. 74-107.

2. Batluk, V. A. Matematychna model protsesu ochyshchennia zapylenoho potoku u vidtsentrovo-inertsiinykh pylovlovliuvachakh [Text] / V. A. Batluk, I. V. Proskurina, A. V. Liashenyk // Promyslova hidravlika i pnevmatyka. - 2010. - No. 1 (27). P. 31-36.

3. Landau, L. D. Teoreticheskaia fizika [Text]. Vol. VI. Gidrodinamika / L. D. Landau. - Moscow: Nauka, 1988. - 736 p.

4. Shakerin, S. Vortex Apparatus and Demonstrations [Text] S. Shakerin // The Physics Teacher. - 2010. - Vol. 48, No. 5. P. 316-318 doi: $10.1119 / 1.3393063$

5. Iliescu, M. S. Analysis of the Cavitating Draft Tube Vortex in a Francis Turbine Using Particle Image Velocimetry Measurements in Two-Phase Flow [Text] / M. S. Iliescu, G. D. Ciocan, F. Avellan // Journal of Fluids Engineering. - 2008. - Vol. 130, No. 2. - P. 021105. doi:10.1115/1.2813052

6. Turik, V. N. Formirovanie vihrei gertlera v vihrevoi kamere [Text] / V. N. Turik, V. V. Babenko, V. A. Voskoboinikov, A. V. Voskoboinikov // Promyslova hidravlika i pnevmatyka. 2009. - No. 3 (25). - P. 31-36

7. Pirashvili, Sh. A. Vihrevoi effekt [Text]. Vol. 1. Fizicheskoe iavlenie, eksperiment, teoreticheskoe modelirovanie / Sh. A. Pirashvili. - Moscow: Nauchtehlitizdat, 2013. - 337 p.
8. Proskurina, I. V. Pryntsypove nove v metodakh ochystky povitria vid pylu v protsesakh vydobuvannia koksu z kamer koksovykh batarei [Text] / I. V. Proskurina // Eastern-European Journal of Enterprise Technologies. - 2009. - Vol. 4, No. 9 (40). P. 12-15. - Available at: \www/URL: http://journals.uran.ua/ eejet/article/view/22271/19949

9. Bona, C. Elements of Numerical Relativity and Relativistic Hydrodynamics [Text] / C. Bona, C. Palenzuela-Luque, C. BonaCasas // Lecture Notes in Physics. - Berlin, Heidelberg: Springer, 2009. - Vol. 783. - 214 p. doi:10.1007/978-3-642-01164-1

10. Pitak, I. V. Issledovanie protsessa mokrogo ulavlivaniia pyli v rotornom vihrevom apparate [Text] / I. V. Pitak // Visnyk natsionalnoho tekhnichnoho universytetu «KhPI». - 2010. No. 17. - P. $135-140$.

11. Thakare, H. R. Experimental, computational and optimization studies of temperature separation and flow physics of vortex tube: A review [Text] / H. R. Thakare, A. Monde, A. D. Parekh // Renewable and Sustainable Energy Reviews. 2015. - Vol. 52. - P. 1043-1071. doi:10.1016/j.rser.2015.07.198

12. Bogomolov, A. On Inertial Systems, Dust Cleaning and Dust Removal Equipment, and Work Areas in the Production of Aerated Concrete from the Hopper Suction Apparatus CSF [Text] / A. Bogomolov, N. Sergina, T. Kondratenko // Procedia Engineering. - 2016. - Vol. 150. - P. 2036-2041. doi:10.1016/ j.proeng.2016.07.290

13. Dekterev, A. A. Sovremennye vozmozhnosti CFD SIGMAFOW dlia resheniia teplofizicheskih zadach [Text] / A. A. Dekterev, A. A. Gavrilov, A. A. Minakov // Sovremennaia nauka. 2010. - No. 2 (4). - P. 117-122.

14. Pitak, I. Study of experimental-industrial design of rotary vortex machine [Text] / I. Pitak // Technology Audit and Production Reserves. - 2014. - Vol. 3, No. 2 (17). - P. 33-38. doi:10.15587/2312-8372.2014.26212

15. Tovazhnianskyi, L. L. Mashyny i aparaty u khimichnykh, kharchovykh i pererobnykh vyrobnytstvakh [Text] / L. L. Tovazhnianskyi, V. P. Shaporev, I. V. Pitak et al. - Kharkiv: Kolehium, 2011. - 610 p.

\section{ОБОСНОВАНИЕ МЕТОДОВ РАСЧЕТА ОСНОВНЫХ ЛАРАМЕТРОВ BИXPEBЫX KAMEP}

На основе построения приближенной модели движения дисперсного потока в вихревом аппарате получены аналитические выражения для определения скорости дрейфа частиц пыли по направлению к стенке аппарата. Проведены расчеты по усреднению тангенциальной и осевой составляющей скорости газового потока. С использованием указанных аэродинамических параметров газового потока определена эффективность пылеулавливания в вихревых аппаратах.

илючевые слова: вихревой аппарат, окружающая среда, дисперсный поток, газовый поток, скорость газа.

Pitak Inna, PhD, Associate Professor, Department of Chemical Technique and Industrial Ecology, National Technical University «Kharkiv Polytechnic Institute»,Ukraine, e-mail: ipitak5@gmail.com, ORCID: http://orcid.org/0000-0002-5073-2942

Shaporev Valery, Doctor of Technical Sciences, Professor, Department of Chemical Technique and Industrial Ecology, National Technical University «Kharkiv Polytechnic Institute», Ukraine, ORCID: http://orcid.org/0000-0003-1652-4688

Briankin Serhii, Head of Course of the Faculty of Military Training, National Technical University «Kharkiv Polytechnic Institute», Ukraine e-mail: serzh2082@ukr.net, ORCID: https://orcid.org/0000-00030444-9107

Pitak Oleg, PhD, Associate Professor, Department of Labour Protection and the Environmental, National Technical University «Kharkiv Polytechnic Institute»,Ukraine, e-mail: opitak77@gmail.com, ORCID: https://orcid.org/0000-0001-5912-4604 